\title{
Failing to Engage: The Politics of Diaspora Policy in Australia
}

Edition 8, 2021

Professor Andrew Rosser

DOI: 10.37839/MAR2652-550X8.8

In 2003, the late Professor Graeme Hugo, one of the country's top migration and population experts, and his collaborators published a major report for the Australian government on the Australian diaspora and associated policy issues. Still the most detailed study of this subject, it recommended that the government adopt a diaspora policy to harness 'the potential of the diaspora to be a positive factor in national economic and social development'. One year later, Dr. Michael Fullilove and Chloë Flutter published another major report on the Australian diaspora, this time for the Lowy Institute, a prominent international affairs think tank. They also called on the government to adopt a diaspora policy to harness its potential for Australia's development.

Diaspora representative organisations then also pushed the case for a diaspora policy, seeing it as an opportunity to press for increased rights for the diaspora. For instance, the Southern Cross Group, the most prominent of these organisations, called on the federal government to adopt a diaspora policy in two separate submissions to the government in 2008 while simultaneously pressing for changes to Australia's election laws to improve expatriate voting rights.

Since then, an array of other prominent individuals and organisations have also expressed support for an Australian diaspora policy including business advisory firm PwC, Advance (an Australian government-linked NGO that runs diaspora engagement activities), the Business Council of Australia (BCA) (a leading business representative organisation), the Asia Society (an Asia-focused think tank), and 
researchers at a number of Australian universities. Significantly, calls for such a policy do not appear to have been diminished by the fact that COVID-19 has seen hundreds of thousands of Australians who were living overseas return home.

In arguably the most important recent contribution to this advocacy, in April this year, the Asia Taskforce-an initiative of the BCA and the Asia Society-published A Second Chance: How Team Australia Can Succeed in Asia. This report recommends that the government adopt a diaspora policy 'to develop a vision for a more connected global Australian community and recognise the important contribution that [Australian expatriates] make while abroard (sic) and upon their return home with new skills'. In so doing, the report suggests, a diaspora policy will help Australian business compete in Asia and the country recover economically from the pandemic.

Generally speaking, there has been little open political pushback against these calls for the government to introduce a diaspora policy. They have not provoked angry opeds in major newspapers, caused people to protest in large numbers on the streets, or in general created much political controversy. Yet so far, the Australian government has baulked at adopting a diaspora policy.

Why is this the case?

I argue that there have been several significant political obstacles to the adoption of a diaspora policy in Australia, notwithstanding the absence of open pushback against proposals for such a move. These include difficulties for proponents of a diaspora policy in keeping the issue of diaspora engagement on the policy agenda, the thin nature of the coalition promoting the cause of diaspora policy, and possible electoral risks for any government that does adopt a diaspora policy. At the same time, though, I suggest that, particularly with the BCA's decision to take up the case for a diaspora policy, the political context may be changing in a way that makes such a policy more politically feasible in the future. 


\section{The state of play}

The Australian government has over the years adopted a range of measures related to the Australian diaspora. For instance, it has passed legislation providing for expatriate dual citizenship, granted Australian expatriates limited voting rights in Australian elections, and provided modest funding to Advance. Most recently, it has denied or delayed entry to Australia to thousands of Australians as part of its attempt to combat COVID-19 through the closure of Australia's borders.

But the Australian government has not so far formulated an overarching diaspora policy to guide Australia's engagement with its diaspora. It is this level of strategic thinking-as well as the political commitment to diaspora engagement that it implies-which proponents of a diaspora policy seek.

Indeed, in 2006, the government explicitly rejected a proposal to formulate such a diaspora policy. In 2005, a Senate inquiry into Australian expatriates-initiated as a result of concern that Australia was 'experiencing a "brain drain"....with damaging consequences for Australia's economy and society'-recommended that the Australian government establish a policy unit within the Department of Foreign Affairs and Trade (DFAT) to, among other things, develop 'a coordinated policy regarding expatriates'.

One year later, then Minister for Immigration and Multicultural Affairs Amanda Vanstone informed the federal parliament that the government would not accept this recommendation on the grounds that DFAT was already doing a fine job of 'promot[ing] the interests of Australian expatriates and of Australia generally in a range of fields including trade, investment and commerce'.

The closest the government has come to adopting a diaspora policy since then has been DFAT's strategy for engaging Australia's so-called 'global alumni', which was introduced in 2016. The principal component of this alumni is international students who have studied in Australia and returned to their countries of origin. While 
predominantly comprising foreign citizens, this group also includes international students who take out Australian citizenship during their time in Australia and then return home. It also includes Australian domestic students who study overseas through programs such as the New Colombo Plan, most of whom are Australian citizens. But while there is some overlap between Australia's global alumni and the Australian diaspora, they are distinct groups, so the global alumni strategy is not tantamount to a diaspora policy.

\section{The case for a diaspora policy}

The Australian government's reluctance to adopt a diaspora policy has not been due to a lack of persuasive arguments for why it should have one. Broadly, the case for a diaspora policy, as articulated by the individuals and organisations mentioned above, runs as follows:

- Australia has a sizeable, talented, and strategically located diaspora. More than one million Australians live abroad-or at least were doing so prior to COVID-19. Mostly, they were living in the United Kingdom, the United States, and New Zealand, but a growing proportion was living in Asia, a region in which Australia has important economic interests. Moreover, this diaspora was young, highly educated and well-regarded by employers.

- These individuals are a resource that the country can harness to promote its own economic development. This is because they can use their market knowledge and networks to promote bilateral trade, facilitate foreign direct investment, and stimulate innovation, increasing productivity and competitiveness. When expatriates return home, 'they bring with them new skills, experience and networks'. This has the potential to assist Australian businesses in overcoming 'the collaboration deficit'-the failure to collaborate with industry partners, especially ones based overseas, in the development of new products and processes.

- Perhaps most importantly, the Australian diaspora is a resource because it 
can help Australian business compete more effectively in Asia. Most Australian companies 'simply don't know how to do business in Asia'. In that context, 'globally connected professionals who understand life in Australia and the way business is done in their corner of Asia and in some cases across the region' and who have relevant language and cultural skills can do much to promote Australian business integration into the region.

- Diaspora policies have become increasingly common across the globe in recent years. Countries such as Ireland, Kenya and Jamaica have formulated official diaspora policies while others such as India, China, the Philippines, Israel and Singapore have become 'conscious of their diaspora communities overseas' and sought 'to capitalise on their links'.

- A diaspora policy is consistent with current thinking about the nature of the migration-development nexus. Whereas early analysis saw outward migration as detrimental to homeland development because of 'brain drain' effects, more recent analysis-and in particular that informed by transnationalism, an analytical perspective that focuses on the 'ties and interactions linking people and institutions across the borders of nationstates'-has suggested that migration can promote development in origin countries. This is because migrants generate flows of money, capital, trade and ideas back to these countries. Diaspora policies are a form of state-led transnationalism aimed achieving a variety of objectives including potentially maximising these flows and their benefits for origin countries.

- The need for a diaspora policy has become more imperative due to COVID-19 because Australia will need to find new sources of economic growth. Asia looms large as a potential market and site of investment. Australia's relationship with China has become more 'complex' in recent times but this is not the only significant market in Asia and, in any case, China remains too important to ignore. In this context, a diaspora policy focused on promoting Asian engagement will be crucial to Australia's ability to rebound from the COVID-19 pandemic. Moreover, news reports about Australians stranded overseas as a result of border closures due to COVID-19 have increased 
awareness of the fact that Australia has a substantial diaspora while highlighting deficiencies in their rights and recognition in Australia.

As noted, these arguments are persuasive. So, why has the Australian government thus far failed to adopt a diaspora policy?

\section{Dissipating concern about a brain drain}

One reason is that concern about Australia suffering a 'brain drain' has largely dissipated since-and to some extent because of-the 2005 Senate inquiry into Australian expatriates. The Senate inquiry found that because Australia operates a skilled immigration program, it 'actually experiences a net "brain gain" of skilled workers' notwithstanding increased outward migration. The inquiry also found that outward migration from Australia produces a range of benefits and opportunities for the country through the linkages that the diaspora forges back to Australia and the skills and expertise expatriates bring to Australia when they return home. Subsequent reports on the Australian diaspora produced by $\mathrm{PwC}$, Advance, the BCA and the Asia Society have echoed these points.

While the case for a diaspora policy has not rested on the implications of brain drain effects so much as the benefits and opportunities having a diaspora presents, dissipation of concern about a 'brain drain' has made it hard for proponents of a diaspora policy to keep the whole issue of outward migration/diaspora engagement on the policy agenda. This has in turn reduced pressure on the Australian government to formulate such a policy.

\section{No special connection}

A second reason why the Australian government has thus far failed to adopt a diaspora policy is that Australia lacks a special connection to its diaspora borne of history, economic importance or size in contrast to countries that have adopted a 
diaspora policy or otherwise sought strategically to exploit diasporic linkages.

The Australian diaspora predominantly comprises first-generation emigrants, having been produced largely by outward migration since the mid-1980s. In this respect, it contrasts with the diasporas of countries such as Ireland, Israel and China which 'have a much longer history and rely heavily on ancestral links in claiming numbers and cultural affinity.' Nor is the Australian diaspora economically important to Australia in the same way as, say, those of the Philippines, Kenya or Jamaica which rely heavily on remittances. Finally, the Australian diaspora is small compared to those of such countries in absolute terms and/or relative to population size.

For instance, Ireland-a country with a national population of less than five million people-claims to have a diaspora numbering in the tens of millions. China's diaspora, while small relative to national population size, is estimated to total as many as 45 million people, almost twice Australia's national population. Even tiny Jamaica, which relies heavily on the remittance economy, has a larger diaspora than Australia. According to its national diaspora policy, its diaspora totals three million people compared to a national population of roughly the same size.

This lack of a special connection to the diaspora has further undermined efforts by proponents of a diaspora policy to keep the whole issue of outward migration/diaspora engagement on the policy agenda.

\section{A differentiated diaspora}

A third reason why the Australian government has so far failed to adopt a diaspora policy is that, while the Australian diaspora is in general highly educated and skilled, it is also differentiated in terms of its human capital endowments and professional and business networks.

For instance, in their analysis of the Australian diaspora, Fullilove and Flutter, argued that the Australian diaspora comprises five distinct elements: 
- the who's who: 'people [who] are at the pinnacle of their careers, in significant international positions';

- gold collar workers: 'Australians [who] are mobile, highly skilled, well paid, and in the early to middle portions of their careers';

- other professionals: 'skilled Australians working in occupations such as nursing and teaching';

- return migrants: 'first or second generation migrants who return to their countries of origin, usually for professional reasons or to retire, and often maintain links with both countries'; and

- rite of passage travellers: 'young Australians [who] tend to be away for shorter periods, often on working holiday visas, and split their time between work and travel'.

Proponents of an Australian diaspora policy generally believe that the first two categories of individuals hold the greatest promise in terms of a potential contribution to Australia's economic development. Yet, although hard data on the composition of the Australian diaspora in these terms is unavailable, it seems likely that these categories account for only a small proportion of the Australian diaspora.

The case for a diaspora policy rests heavily on the notion that the Australian diaspora has scarce human capital and networks that Australia needs. Yet the likelihood that the relevant sections of the Australian diaspora are small complicates efforts to promote a diaspora policy as opposed to other forms of diaspora engagement. Specifically, it implies that small, targeted programs such as Advance or DFAT's global alumni engagement strategy may be more appropriate forms of diaspora engagement than high-level strategic initiatives such as a diaspora policy. This further complicates efforts to keep adoption of a diaspora policy on the policy agenda. 


\section{Potential criticism}

A fourth reason why the Australian government has so far failed to adopt a diaspora policy is that adoption of such a policy could leave it vulnerable to criticism that it is privileging 'elites' (especially diasporic elites) over 'ordinary Australians'. This would particularly be the case to the extent that a diaspora policy provided additional rights or benefits to members of the diaspora.

There is a precedent in this respect. Criticism along these lines emerged from the far right of Australian politics during the 1990s when the Hawke/Keating and Howard governments were considering changes to Australia's citizenship legislation to provide for expatriate dual citizenship.

Bruce Ruxton, the then head of the Returned and Services League (RSL) and a figure known for opposition to Asian immigration, expressed concern that Australian citizenship could become a 'flag of convenience' for persons who do not have a real commitment to Australia.[1] Likewise, Pauline Hanson, the head of One Nation, a xenophobic anti-immigration party, argued that: 'In the new globalised world the concept of nation, and of citizenship, is being eroded.....Australia should be a sovereign nation, not merely a geographical area populated by "world citizens"'.

These critiques were significant enough politically at that time to delay adoption of expatriate dual citizenship by roughly a decade.[2]

As noted above, diaspora policy is not the sort of issue that sits at the centre of political debate in Australia. But regardless of which major party is in power, Australia's political leaders could be wary of provoking such a response for fear that it could contribute to a loss of votes in a few key marginal electorates. 


\section{A thin base of support}

A fifth and final reason why the Australian government has so far failed to adopt a diaspora policy is that the coalition of actors advocating for a diaspora policy has until recently been very thin.

As noted above, the case for a diaspora policy was initially made by a few prominent experts in the university and think tank sectors as well as diaspora groups. But, otherwise, few other prominent individuals or organisations supported the cause during these early days. Most notably, the business community did not advocate strongly for such a policy.

For instance, in its 2004 submission to the Senate's inquiry into Australian expatriates, the BCA focused mainly on calling for the removal of taxation-related and other impediments to Australia's competitiveness in global labour markets, including ones that discourage expatriates from returning home. It stated that: 'Consideration could be given to whether more formal programs or avenues of communication could be developed to better, and more actively, promote and engage contact with expatriates.' But it stopped short of calling for a diaspora policy.

Business support for a diaspora policy has been undermined by the fact that Australian business has a strong domestic focus: as prominent businessman Sir Rod Eddington has put it, Australian businesses 'are basically domestic companies'. It is also not especially innovative. Business expenditure on research and development in Australia is low by OECD standards and has been in decline since its peak in 2008-2009, mainly as a result of reduced mining sector investment in $R \& D$. Moreover, as Innovation and Science Australia has noted, 'the vast majority of innovation introduced by Australian businesses has a low degree of novelty and relies upon the adoption and adaptation of existing technology and knowledge (i.e. following best practices)'. This lack of interest in overseas markets and capacity to innovate reduces business demand for diasporic labour knowledgeable in new ways of doing things and by extension in diaspora engagement. 
This thinness of the coalition advocating for a diaspora policy has further limited pressure on the government to develop such a policy.

\section{Is change afoot?}

Over the past five or so years, the Australian business community has become more actively involved in discussions over diaspora policy in Australia, particularly as a result of PwC's and the BCA's involvement in the reports noted earlier. So, this situation may be in the process of changing.

How things play out from here, however, will depend on whether these organisations, and especially the BCA as one of the country's leading business representative organisations, remains engaged in the push for a diaspora policy and can marshal broader support from the business community for this push. If the business community articulates clear support for a diaspora policy, Australia's political leaders may be prepared to overlook the political risks such a policy presents.

Early signs may indicate such a willingness. In launching the 2021 Asia Taskforce report Australia's Minister for Trade Dan Tehan said that he 'look[s] forward to working with the taskforce, to implementing [the report's] 24 recommendations'.

While the main body of the report includes a call for a diaspora policy, this is (oddly) not explicitly repeated in the section on recommendations. But the recommendations do include several that imply the existence of such a policy or at least a more strategic approach to diaspora engagement.

These include i) that the government appoint a 'National Talent Commissioner to coordinate government and business policies and programs' in relation to AsianAustralian, diaspora and alumni groups; and ii) that 'business and government should work together to elevate the role of [these elements] in advancing Australia's economic and soft-power objectives'. 
Of course, if the Australian government decides to produce a diaspora policy, the politics of diaspora policy will shift towards shaping its content. Here the utilitarianism of groups such as the BCA, the Asia Society and $\mathrm{PwC}$-manifest in their view of diaspora policy as a tool for enhancing Australia's economic competitiveness-and the more rights-based concerns of diaspora groups will doubtless be fundamental to debate.

Image credit: Michael Yat Lee/Flickr

[1] The Age, 5 September 1992; Herald Sun, 3 October 2000.

[2] Rosser, Andrew and Guangyu Qiao-Franco (forthcoming) 'Explaining Variations in State Policies on Expatriate Dual Citizenship: Insights from Australia and Indonesia'. 